\title{
Regulatory RNAs and Cardiovascular Disease - With a Special Focus on Circulating MicroRNAs
}

\author{
D. DLOUHÁ ${ }^{1}$, J. A. HUBÁČEK ${ }^{1}$ \\ ${ }^{1}$ Centre for Experimental Medicine, Institute for Clinical and Experimental Medicine, Prague, \\ Czech Republic
}

Received November 9, 2016

Accepted December 23, 2016

\begin{abstract}
Summary
MicroRNAs (miRNAs) are a class of short non-coding regulatory RNA molecules which play an important role in intracellular communication and cell signaling and which influence cellular processes such as proliferation, differentiation, and cellular death. Over the past two decades, the crucial role of microRNAs in controlling tissue homeostasis and disease in cardiovascular systems has become widely recognized. By controlling the expression levels of their targets, several miRNAs have been shown to modulate the function of endothelial cells (miR-221/222 and -126), vascular smooth muscle cells (miR-143/145) and macrophages (miR-33, -758, and -26), thereby regulating the development and progression of atherosclerosis. The stability of miRNAs within the blood suggests that circulating miRNAs may function as important biomarkers of disease development and progression. Numerous circulating miRNAs have been found to be dysregulated in a wide variety of different disease states, including diabetes, cancer, and cardiovascular disease.
\end{abstract}

\section{Key words}

Cardiovascular disease - Cholesterol • Epigenetic • miRNA • Non-coding RNA • Regulation

\section{Corresponding author}

D. Dlouhá, IKEM-CEM-DCMR, Videnska 1958/9, 14021 Prague 4, Czech Republic. E-mail: dadl@ikem.cz

\section{Background}

Despite the tremendous progress in diagnosis and treatment, cardiovascular disease (CVD) remains one of the leading causes of death in developed countries. In addition to the well-known environmental risk factors (smoking, lack of physical activity), genetic predispositions play an important role in CVD development.

Genome-wide association studies have revealed many changes within DNA sequence leading to increased risk of CVD development (Dubé and Hegele 2013). These changes/polymorphisms can either be associated with genetic markers such as variants within sortilin-1 (Kathiresan et al. 2008) and apolipoprotein A5 (Hubáček 2016), or they can be totally independent on traditional risk factors such as the markers on chromosome 9 (Roberts and Stewart 2012).

Nevertheless, a substantial proportion of CVD genetic risk remains unknown ("missing heritability") and it is supposed that epigenetic factors may be at least partially responsible for the "remaining" genetic risk of CVD (Muka et al. 2016).

Of the possible epigenetic mechanisms that lead to disease development, in addition to DNA methylation (almost exclusively cytosine methylation within the sequences with a high proportion of $\mathrm{CG}$ repeats) and histone modification (methylation, acetylation, phosphorylation, ubiquitination) more and more attention is now being focused on the analysis of regulatory RNA molecules (Udali et al. 2013, Kuneš et al. 2015, Kura et al. 2016).

Only $1-2 \%$ of the human genome codes for mRNAs build a basis for protein synthesis. In contrast, there are many more non-coding RNAs (ncRNAs) in the genome, most of which have unknown functions. NcRNAs can be divided into infrastructural ncRNAs and 
regulatory ncRNAs. Regulatory ncRNAs can be classified into Piwi-interacting RNAs (piRNAs), small interfering RNAs (siRNAs), microRNAs (miRNAs), and long non-coding RNAs (lncRNAs) (Thum 2015).

The majority of non-protein-coding transcripts belong to the group of IncRNAs. LncRNAs vary in size from $200 \mathrm{bp}$ to $>100 \mathrm{~kb}$, are transcribed by RNA polymerase II, and are often spliced and polyadenylated. LncRNAs are usually localized in the nucleus, have a much lower rate of expression than miRNAs, and exhibit a lower ratio of similarity. They have been identified using a variety of means and the number of specific lncRNAs shown to influence genomic function is growing. These include lncRNAs with roles in imprinting, enhancer function, $\mathrm{X}$ chromosome inactivation, chromatin structure, and genomic rearrangements during the generation of antibody diversity. They appear to be critical for normal development and, in many cases, are deregulated in diseases such as cancer. LncRNAs include long intergenic ncRNAs, long intronic ncRNAs, telomeric ncRNAs transcribed from sub-telomeric promoters (telomeric repeat-containing RNA), pseudogene transcripts, circular RNAs, enhancer RNAs, and transcribed-ultraconserved regions (Caley et al. 2010, Kumarswamy and Thum 2013).

Probably the best known lncRNA is ANRIL (antisense non-coding RNA in the INK4 locus) identified at the 9p21.3 location. Variants within this lncRNA are associated with enhanced risk of coronary artery disease development, intracranial aneurysm, type 2 diabetes (T2DM), and some types of cancer (Pasmant et al. 2011).

PiRNAs are small ncRNAs of 24-31 nucleotides (nt) in size, and named for their ability to form complexes with Piwi proteins of the Argonaute family. The primary role of these small RNAs has been shown to be the suppression of transposon activity during the germline cycle. Transposon control also occurs in mammals during spermatogenesis through de novo DNA methylation (Iwasaki et al. 2015).

SiRNAs are linear perfectly base-paired dsRNAs, which are processed by Dicer into 20-24 nt siRNAs that direct silencing when loaded onto the RNA-induced silencing complex (RISC). They mediate post-transcriptional silencing similar to miRNA silencing. Compared with miRNAs, guide strand recognition is indistinguishable. In addition, siRNAs have also been found to direct sequence-specific transcriptional gene silencing by increasing epigenetic marks characteristic of heterochromatin (Kaikkonen et al. 2011).

MiRNAs are short non-coding single-stranded RNA molecules, $\sim 22 \mathrm{nt}$ in length, which act as posttranscriptional regulators. MiRNAs derive from transcripts that form distinctive hairpin structures. Processing of the hairpin into mature miRNA by Drosha and Dicer allows interaction with Argonaute (Ago) proteins to form RISC. Strand selection for RISC is dictated by the thermodynamic stabilities of the two duplex ends: the strand that has its $5^{\prime}$ terminus at the less stable base-paired end of the duplex is mostly favored (MacFarlane et al. 2010) (Table 1). The miRNAs then pair with mRNAs by binding to different target-gene regions: the 3'-untranslated region (3'UTR), 5'UTR, and promoter or coding sequences that repress or activate translation. The crucial binding location for translational regulation resides in the mature miRNA sequence, more accurately within the nucleotides $2-7$ or $2-8$ from the 5 ' end of the miRNA, called the seed region (Obsteter et al. 2015). The mechanisms by which miRNAs reduce protein output are mostly triggered either by deadenylation of the target mRNA and inhibition of eukaryotic initiation factors, or by interference with translational elongation. In addition, the miRNA response has been reported to switch from inhibition of gene expression to enhancement, thereby inducing upregulation of target mRNAs during cell cycle arrest and repressing translation in proliferating cells.

MiRNAs are conserved in a wide range of organisms, from nematodes to humans (Kaudewitz et al. 2015). About 1,500-2,000 human miRNAs have been identified, and it is estimated that $>60 \%$ of all proteincoding genes are directly regulated by miRNAs. Furthermore, any given miRNA may bind to and regulate $>1$ target, sometimes as part of the same signaling pathway. Conversely, any given miRNA may harbor several distinct miRNA-binding sites within its 3'-UTR, adding multiple levels of regulation. As such, miRNAs are fine-tuners of gene expression patterns in response to pathophysiological stimuli. Most miRNAs are more ubiquitously expressed and are not cell-type specific. Thus, although many miRNAs are expressed at relatively low levels under basal conditions, they are strongly upregulated during pathological stress (Thum 2015).

Because we consider the area of this epigenetic research very important, we focused in this review on the role of miRNAs on cardiovascular disease, especially atherosclerosis. 
Table 1. Basic components of miRNAs biogenesis. MiRNA transcripts are encoded both in intergenic regions and within introns of genes, and can be transcribed either through their own promoters or in concert with their host genes. In the canonical miRNA biogenesis pathway, transcript pri-miRNA is transcribed by the Polymerase II enzyme, after which it undergoes processing by the Drosha/DGCG8 complex to generate pre-miRNA. Following export to the cytoplasm, a pre-miRNA undergoes further cleavage by DICER to generate a mature miRNA duplex of 18-22 nt in length. Argonaute proteins then help mediate the separation of the miRNA strands and incorporation into the RISC. Within the RISC, miRNAs bind partially complementary target sites, primarily within mRNA 3'untranslated regions (3'UTRs), resulting in translational repression and/or mRNA destabilization.

\begin{tabular}{|c|c|c|c|}
\hline Component & Description & Function & Location \\
\hline Pri-miRNAs & $\begin{array}{l}\text { Long RNA precursors, several } \\
\text { hundred or thousands of nucleotides } \\
\text { long, has a } \approx 33 \text {-nt stem-loop } \\
\text { configuration comprising a } 5^{\prime} \text { end } \\
\text { cap structure and a polyadenylated } \\
3^{\prime} \text { tail sequence. }\end{array}$ & $\begin{array}{l}\text { Primary transcripts }- \text { primary miRNA } \\
\text { precursor. }\end{array}$ & \\
\hline Drosha & Ribonuclease type III. & $\begin{array}{l}\text { Responsible for cropping pri-miR into pre-miR } \\
\text { through a single-stranded RNA-double- } \\
\text { stranded RNA junction-anchoring model. }\end{array}$ & \\
\hline DGCR8 & $\begin{array}{l}\text { Double-stranded RNA-binding } \\
\text { protein DiGeorge syndrome critical } \\
\text { region gene } 8 .\end{array}$ & $\begin{array}{l}\text { Together with Drosha forms a protein complex } \\
\text { which cleaves the pri-miRNA. DGCR } 8 \\
\text { recognizes the pri-miRNA at the ssRNA- } \\
\text { dsRNA junction and directs Drosha to } \\
\text { a specific cleavage site } \sim 11 \text { bp from the } \\
\text { junction on the stem where Drosha cuts to } \\
\text { liberate a } \sim 60-70 \mathrm{bp} \text { miRNA hairpin } \\
\text { pre-miRNA. }\end{array}$ & Nucleus \\
\hline Pre-miRNAs & $\begin{array}{l}\text { 70 nucleotide intermediate, long } \\
\text { stem-loop structure. }\end{array}$ & Precursor miRNAs. & \\
\hline Exportin5 & $\begin{array}{l}\text { Ran-GTP dependent nuclear } \\
\text { transport receptor }(\text { Exp5)/RanGTP. }\end{array}$ & $\begin{array}{l}\text { Hydrolysis of RanGTP to RanGDP releases the } \\
\text { pre-miR in the cytoplasm. }\end{array}$ & \multirow{6}{*}{ Cytoplasm } \\
\hline Dicer & $\begin{array}{l}\text { Ribonuclease type III. } \\
\text { Multi-domain protein. }\end{array}$ & $\begin{array}{l}\text { Pre-miR is processed into } 18-\text { to } 22-\mathrm{nt} \mathrm{miR} \\
\text { duplex (miR:miR*) by Dicer, which is } \\
\text { associated to another dsRBP. The duplex is } \\
\text { probably unwound by a helicase activity, and } \\
1 \text { strand ("passenger" strand) is degraded, } \\
\text { whereas the other strand ("guide" strand) } \\
\text { accumulates as a mature miR. }\end{array}$ & \\
\hline TRBP & $\begin{array}{l}\text { Transactivating response RNA- } \\
\text { binding protein. }\end{array}$ & $\begin{array}{l}\text { TRBP associates with Ago } 2 \text { and Dicer to play } \\
\text { an integral role in the miRNA pathway. }\end{array}$ & \\
\hline PACT & Protein Kinase R-activating protein & & \\
\hline Ago2 & $\begin{array}{l}\text { Argonaute } 2 \text { protein with } \\
\text { endonuclease activity. } \\
\text { Ago } 2 \text { is the only argonaute protein } \\
\text { with "slicer" activity capable of } \\
\text { catalyzing cleavage of mRNA. }\end{array}$ & $\begin{array}{l}\text { Dicer, TRBP and Ago } 2 \text { form a protein complex } \\
\text { that recognizes and binds the pre-miRNA. } \\
\text { Ago2 loads miRNA guide in RISC. }\end{array}$ & \\
\hline RISC & $\begin{array}{l}\text { RNA induced silencing complex. } \\
\text { Core components: Dicer, Ago2, } \\
\text { PACT and TRBP. }\end{array}$ & $\begin{array}{l}\text { RISC serves as a guide, directing the silencing } \\
\text { of target mRNA. Mature miRNAs are coupled } \\
\text { with RISC and then regulate the target genes. }\end{array}$ & \\
\hline
\end{tabular}




\section{MiRNAs in medicine}

Numerous diseases, including cardiovascular disease and pathophysiology, are associated with the regulation of miRNA expression. MiRNAs have been identified as playing a key role in organ development, cellular differentiation, proliferation, and function.

\section{Intracellular miRNAs}

Intracellular miRNAs are more abundant then extracellular miRNAs. In one study, over 250 small RNA libraries from 26 different organ systems and cell types of humans and rodents were sequenced to assess their expression patterns (Landgraf et al. 2007). The expression of some miRNAs is highly tissue-specific, e.g. miR-1 and -133 (cardiac and skeletal muscle), miR-122 (liver), and miR-124a (brain) (Lagos-Quintana et al. 2002). Among others, kidney-specific miRNAs (miR-192, -194, -204, and -215) have low expression in the liver, lung and heart (Landgraf et al. 2007). MiR-375 and -449 are lung tissue-specific (Williams et al. 2009).

Of the cardiac-specific miRNAs, miR-1 acts as a regulator of differentiation and proliferation during cardiogenesis and as a regulator of cardiomyocyte growth in the adult heart. MiR-133, transcribed from the same chromosomal loci as miR-1, enhances myoblast proliferation and is thus involved in cardiomyocyte proliferation (Chen et al. 2006). The miR-208 family, which includes miR-208a/b and -499 (exclusively expressed in the heart), are reported to play a pathological role in cardiac hypertrophy and, consequently, arrhythmia. MiR-499 has been shown to be downregulated under pathological conditions such as ischemia and cardiac remodeling (Rawal et al. 2014). MiR-21 is mechanistically involved in cardiac fibrosis development (Thum 2015). The neurologically enriched miR-212/132 family becomes activated during heart failure (HF) in human and animal models and has been shown to regulate cardiac hypertrophy in cardiomyocytes (Ucar et al. 2012).

Diabetes is a strong risk factor for the development of CVD. Significant differences have been found in the miRNA expression profiles of various tissues in T2DM patients and hyperglycemic animal models (Feng et al. 2016) in comparison to healthy subjects, e.g. the pancreas (miR-375, -184, and -33), adipose tissue (miR-93 and -223), and the liver (miR-143).

\section{Extracellular miRNAs}

Extremely stable miRNAs also occur in extracellular fluids, e.g. serum, saliva, urine, milk, and tears. Concentrations of miRNAs in body fluids are low, which means they are likely to be more effectively detected.

MiRNAs can be released into the blood circulation by various mechanisms, including active secretion, apoptosis, and necrosis. These miRNAs circulate in different types of vesicles, such as apoptotic bodies, microvesicles, exosomes, and lipoproteins. It has been reported that a significant portion of circulating miRNAs in human plasma and serum is associated with Ago2 (Russo et al. 2014). Although miRNAs are mostly by-products of cellular activities and cell death, certain miRNA species may also function in cell-cell communication (Turchinovich et al. 2012).

Circulating miRNAs may be considered putative biomarkers of the cardiovascular system. A sensitive, specific, and non-invasive diagnostic blood test for CVD would be very desirable because it is difficult to obtain valid biopsies from patients. The ability to detect circulating miRNAs also provides an effective means for non-invasive detection and diagnosis in patients with CVD. Recent advancements in detection methods for circulating miRNAs present in the serum/plasma may become a powerful tool when performing minimally invasive diagnosis of different CVDs. Numerous studies have demonstrated that alterations in the spectrum of extracellular miRNAs are correlated with various cardiovascular conditions such as myocardial infarction (MI) (miR-1, -133a/b, and -499), hypertrophy (miR-29, -21), dilated cardiomyopathy (miR-423-5p), and arrhythmias (miR-29, -150) (Wang et al. 2010, Liu Z et al. 2012, Dawson et al. 2013, Roncarati et al. 2014).

In a patient cohort with ST-segment elevation MI, the early use of circulating miR-detection (miR-1, $-133 a,-133 b$, and $-499-5 p$ ) in comparison with troponins as biomarkers was conclusively reported (D'Alessandra et al. 2010). Recently, Wang et al. (2016) found that circulating miR-19b-3p, -134-5p, and -186-5p are promising novel diagnostic biomarkers for the early phase of acute MI. Cardiac damage caused by MI, viral myocarditis, diastolic dysfunction, and acute heart failure has been reported as initiating the release of cardiomyocyte-specific miR-208b and -499 into circulation (Corsten et al. 2010). Other reports demonstrate decreased levels of miR-29 and -150 and 
increased serum levels of miR-423-5p, -320a, -22, and $-92 \mathrm{~b}$ in subjects with systolic HF and atrial fibrillation (Goren et al. 2012, Goren et al. 2014). In another study, plasma concentrations of miR-126 were found to be reduced in patients with HF compared to healthy subjects (Fukushima et al. 2011).

Zhang et al. (2015) found that plasma miR-126 expression was significantly reduced in T2DM patients, which suggests that this miRNA may serve as a potential marker for the early prediction of diabetes. Coronary artery disease (CAD) is a complication of T2DM, and different circulating miR-126 expression patterns in the plasma of T2DM patients may serve as a biomarker of diabetic CAD (Al-Kafaji et al. 2016).

Diabetic nephropathy (DN) is one of the most serious complications of diabetes. Recently, a prospective case-control study showed that miR-21, $-29 \mathrm{a} / \mathrm{b} / \mathrm{c}$, and -192 reflect DN pathogenesis and may be of clinical significance in monitoring and preventing DN advancement (Chien et al. 2016). In Figure 1 are summarized the most prominent microRNAs involved in CVD pathogenesis.

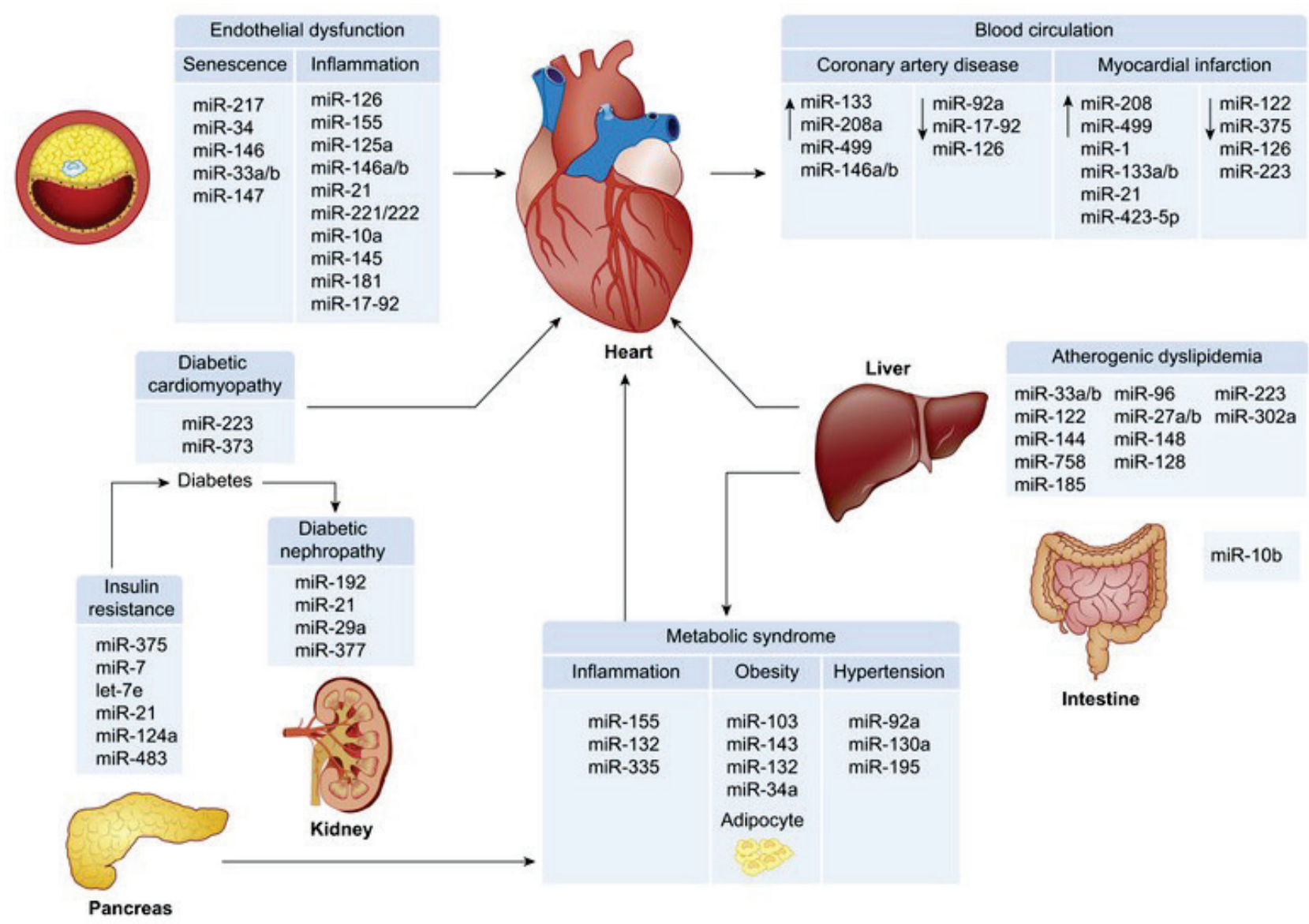

Fig. 1. Summarized features of the known roles of microRNAs in the development of CVD. Different up- and down-regulated microRNAs participate in the progression of endothelial dysfunction and regulations of metabolic processes.

\section{The role of miRNAs in the development of atherosclerosis}

Atherosclerosis is the underlying condition in most CVD. Lipid and endothelial dysfunction, inflammation, immune response, and advanced ageing are major factors involved in the initiation and progression of atherosclerosis. Recent studies have shown the key roles of several miRNAs in endothelial dysfunction, cholesterol homeostasis, reverse cholesterol transport, plaque development, neoangiogenesis, and plaque rupture (Zampetaki et al. 2013, Menghini et al. 2014) (Tables 2, 3 and 4).

\section{Endothelial dysfunction}

Several miRNAs are involved in the modulation of endothelial dysfunction (Table 2) such as miR-10a, which inhibits a number of pro-inflammatory genes in 
endothelial cells (ECs), including vascular cell adhesion molecule 1 (VCAM-1), E-selectin, and the nuclear factor

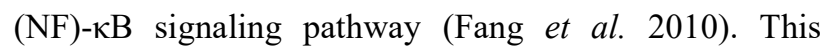
signaling pathway is also modulated by miR-181b, which directly targets the importing karyopherin subunit alpha-4

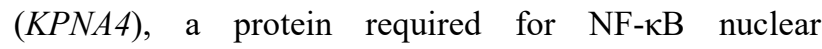
translocation (Sun $X$ et al. 2012). MiR-126, -31, and $-17-3 p$ also regulate vascular inflammation by controlling the expression of the adhesion molecules VCAM-1, intercellular adhesion molecule 1 (ICAM-1), and E-selectin (Suarez et al. 2010, Asgeirsdottir et al. 2012).
In addition to pro-inflammatory cytokines, shear stress also regulates endothelial cell activation through miRNAs. In this regard, atheroprotective laminar shear flow downregulates miR-92a and consequently increases the expression of well-known targets of this miRNA, such as Kruppel-like factors $(K L F 2 / 4)$ (Wu et al. 2011, Fang and Davies 2012). Some other miRNAs have important roles in endothelial ageing such as miR-146a, which delays EC senescence, and miR-217 and -34a, which promote EC senescence (Menghini et al. 2009, Ito et al. 2010, Vasa-Nicotera et al. 2011).

Table 2. MiRNAs associated with endothelial dysfunction.

\begin{tabular}{|l|l|l|}
\hline miRNA & Targets & Functions \\
\hline miR-10a & MAP3K7; TAK1; $\beta$ TRC, HOXA1 & $\begin{array}{l}\text { Inhibits upstream canonical NF- } \kappa B \text { signaling pathway } \\
\text { Reduces vascular inflammation in vivo }\end{array}$ \\
\cline { 1 - 2 } miR-181b & Importin $\alpha-3$ & $\begin{array}{l}\text { Inhibits leukocyte adherence to ECs. Regulates angiogenic } \\
\text { signaling and vascular integrity }\end{array}$ \\
\cline { 1 - 2 } miR-126 & CXCL12 & Decreases leukocytes adhesion to activated ECs \\
\cline { 1 - 2 } miR-17-3p & ICAM1 & Regulates or contributes to flow-mediated EC activation \\
\cline { 1 - 2 } miR-92a & KLF4/2 & EC senescence, suppresses cell proliferation \\
\cline { 1 - 2 } miR-34 & SIRT1 &
\end{tabular}

Table 3. MiRNAs involved in regulation of cellular cholesterol metabolism.

\begin{tabular}{|c|c|c|}
\hline miRNA & Targets & Function \\
\hline $\mathrm{miR-33a/b}$ & $\begin{array}{l}\text { ABCA1, ABCG1, NPC1, CPT1A, SIRT6, } \\
\text { AMPK, HADHB, CROT, CYP7A1, ABCB11, } \\
\text { ATP8B1, NSF, SRC3, PCK1, G6PC, IRS2, } \\
\text { RIP140, NFYC, SREBP1 }\end{array}$ & $\begin{array}{l}\text { Cholesterol efflux, HDL biogenesis, intracellular } \\
\text { cholesterol transport, fatty acid oxidation, insulin } \\
\text { signaling and glucose metabolism }\end{array}$ \\
\hline miR-122 & SREBP, MTTP, Klf6 & $\begin{array}{l}\text { Fatty acid oxidation, cholesterol synthesis. Lipids } \\
\text { accumulation in liver, fibrosis and tumor } \\
\text { formation }\end{array}$ \\
\hline $\operatorname{miR} 185 / 342$ & SREBP & Fatty acid oxidation, cholesterol metabolism \\
\hline miR-370 & $\begin{array}{l}\text { ABCA1; CPT1a, FASN, NR1H3, ACACA, } \\
\text { SREBP }\end{array}$ & $\begin{array}{l}\text { Cholesterol efflux, HDL biogenesis, fatty acid } \\
\text { oxidation }\end{array}$ \\
\hline miR-27b & PPAR $\alpha, \mathrm{C} / \mathrm{EBP} \alpha$, ANGPTL3, NDST 1 & Lipid metabolism, adipocyte differentiation \\
\hline miR-27a & $\begin{array}{l}\text { RXR } \alpha, \text { ABCA1, FASN, SREBP1/2, PPAR } \alpha / \gamma, \\
\text { ApoA1, ApoB100, ApoE }\end{array}$ & Lipid metabolism, cholesterol efflux \\
\hline $\begin{array}{l}\operatorname{miR}-302 a \\
\text { miR-758 } \\
\text { miR-144 } \\
\text { miR-106b }\end{array}$ & ABCA1 & Cholesterol efflux \\
\hline miR-10b & ABCA1; ABCG1 & \\
\hline mir-26 & ABCA1; ARL7 & Cholesterol efflux, HDL biogenesis \\
\hline
\end{tabular}




\section{Cholesterol homeostasis}

Cholesterol is a key player in every stage of atherosclerosis development, and its membrane levels are mainly regulated at the transcriptional level by endoplasmic reticulum (ER)-bound sterol regulatory element-binding proteins (SREBPs) (Brown and Goldstein 1977). There are two SREBP genes, SREBP1 and $S R E B P 2$, which encode three different transcripts. SREBPIa and SREBP2 activate the transcription of cholesterol metabolism-related genes including 3-hydroxy-3-methylglutaryl coenzyme A reductase $(H M G C O A R)$ and the low-density lipoprotein receptor $(L D L-R)$, while SREBPlc enhances the expression of fatty acid metabolism-related genes such as fatty acid synthase (FAS) (Kim et al. 1995). Of the miRNAs that target the HDL/reverse cholesterol transport pathway, miR-33a and $-33 b$ are intronic miRNAs that are co-expressed with their host genes SREBF1 and SREBF2, which code for transcription factors that regulate cholesterol and FAS (Feinberg and Moore 2016). On the other hand, miR-33a and $-33 \mathrm{~b}$ target genes involved in cholesterol reflux, ATP-binding cassettes ( $A B C A 1$ and $A B C G 1)$, and fatty acid oxidation (HADHB, CROT, CPTla and AMPKal). Inhibition of miR-33 using modified antisense or locked nucleic acid oligonucleotides increases hepatic $A B C A 1$ expression and plasma HDL-C levels in both mice and monkeys by $40-50 \%$ and enhanced cholesterol transport from macrophages to the plasma, liver, and feces by $>80 \%$ (Rayner et al. 2011).

MiR-122 is the most abundant miRNA in the liver, accounting for more than $80 \%$ of the total miRNA content in this organ. Inhibition of miR-122 levels in the liver results in a significant reduction of plasma cholesterol levels in mice and non-human primates (Elmen et al. 2008). Micro-array and gene expression analyses in animals show that inhibition of miR-122 in the liver results in the downregulation of several genes involved in cholesterol synthesis, e.g. HMGCS1, $H M G C o A R$, and squalene epoxidase. Thus, miRNAs seem to play an important role in modulating cholesterol and fatty acid metabolism (Madrigal-Matute et al. 2013, Zampetaki et al. 2013, Menghini et al. 2014) (Table 3).

\section{Plaque development}

Lipid uptake and inflammatory responses in monocytes/macrophages are regulated by miRNAs such as miR-155 and -125a-5p (Huang et al. 2010, Chen et al. 2009). As a result, neointimal accumulation of foam cells and fatty streaks can be reduced, which is a main determinant of plaque development and instability. Vascular differentiation and apoptosis are regulated by transforming growth factor- $\beta$, which is a known target of miR-26a (Leeper et al. 2011). Metalloproteinase (MMP) expression, such as MMP2/9, controls vascular smooth muscle cell (VSMCs) proliferation. MiR-29b is upregulated in VSMCs treated with ox-LDLs and targets $M M P 2$, thereby reducing VSMC migration (Chen et al. 2011). The vascular wall surrounding foam cells and extracellular lipid droplets (lipid core) is characterized by a switch from a contractile to a secretory phenotype in VSMCs. This phenotype switch may be modulated by miR-145, which favors a contractile phenotype, through the upregulation of KLF4 and myocardin (Lovren et al. 2012). The fibroatheroma evolves into a more complicated plaque, often characterized by calcification that is regulated in VSMCs by miR-125b through targeting osteoblast transcription factor SP7 (Goettsch et al. 2011).

\section{Neoangiogenesis}

Normal vessels are nurtured through oxygen diffusion from the lumen of the adventitial vasa vasorum. But as the intimal wall thickens, the oxygen-effective diffusion distance becomes impaired and the vasa vasorum proliferates in the inner layers of the vessel wall. Neovessel formation is regulated by miR-222/221 and -155 , which target endothelial nitric oxide synthase (Sun HX et al. 2012), and by miR-222, which silences the signal transducer and activator of transcription 5A (STAT5A) (Dentelli et al. 2010). Another interesting miRNA that regulates angiogenesis is the miRNA cluster miR-17-92 (Table 4). MiR-17-92 expression is regulated by vascular endothelial growth factor and targets thrombospondin-1, an antiangiogenic molecule (Suarez et al. 2008).

\section{Plaque rupture}

Neoangiogenesis and intraplaque hemorrhage drive blood components to the atherosclerotic lesion, promoting plaque vulnerability due to the enrichment of pro-inflammatory, pro-oxidant, and proteolytic factors. This pro-inflammatory scenario may be promoted by miR-146a, which drives peripheral blood mononuclear cells (PBMCs) towards a Th1 response (Guo et al. 2010). In this regard, miR-29 inhibits the expression of Col3A1 and elastin $(E L N)$, thus reducing vascular integrity. Interestingly, miR-29 expression has been shown to be upregulated in aortic aneuryms from fibulin-4 knockout and fibrillin transgenic mice (Li et al. 2009). MiR-365 
can function as a pro-thrombotic factor by stimulating endothelial apoptosis, whereas miR-21 protects VSMCs from $\mathrm{H}_{2} \mathrm{O}_{2}$-induced apoptosis (Lin et al. 2009). MiR-221 and -222 have opposite effects in VSMCs and ECs, protecting from apoptosis or promoting cell death, respectively (Liu X et al. 2012).

Table 4. MiRNAs participated in vascular remodeling.

\begin{tabular}{|c|c|c|c|}
\hline miRNA & Targets & Function & \\
\hline miR-155 & $\begin{array}{l}\text { Bcl6, HBP1, AT1R; } \\
\text { Ets-1; IL13 receptor } \alpha 1\end{array}$ & Regulation of angiogenesis and inflammation & \multirow{6}{*}{ Plaque development } \\
\hline miR-125a-5p & $\begin{array}{l}\text { LOX-1; CD68; SRB1, } \\
\text { ORP9 }\end{array}$ & $\begin{array}{l}\text { Lipid uptake, cytokine expression, oxLDL } \\
\text { internalization }\end{array}$ & \\
\hline miR-29b & DNTMP3b & $\begin{array}{l}\text { Regulation of oxLDL mediated human aortic } \\
\text { SMCs }\end{array}$ & \\
\hline $\operatorname{miR}-143 / 145$ & Klf4, myocardin, Elk-1 & $\begin{array}{l}\text { Promote differentiation and repress } \\
\text { proliferation of SMCs }\end{array}$ & \\
\hline miR-125b & IRF4 & Inflammatory response of macrophages & \\
\hline miR-26a & SMAD-1 & $\begin{array}{l}\text { Protecting VSMCs from differentiation and } \\
\text { apoptosis }\end{array}$ & \\
\hline $\operatorname{miR-222/221}$ & Ets-1 & Endothelial apoptosis regulation & \multirow{4}{*}{ Neoangiogenesis } \\
\hline miR-155 & AT1R; Ets-1 & $\begin{array}{l}\text { Protective role in development of endothelial } \\
\text { inflammation }\end{array}$ & \\
\hline miR-17-92 & $\begin{array}{l}\text { ABCA1; LDLR; } \\
\text { SEMA6A }\end{array}$ & \multirow{2}{*}{$\begin{array}{l}\text { Cholesterol efflux; promoting of angiogenesis } \\
\text { by regulation of ECs repulsion }\end{array}$} & \\
\hline $\mathbf{m i R - 2 7 a / b}$ & ABCA1; SEMA6A & & \\
\hline $\mathrm{miR-146a/b}$ & TLR4; IRAK1; TRAF6 & Lipid accumulation, inflammatory response & \multirow{4}{*}{ Plaque rupture } \\
\hline miR-29a & LPL & $\begin{array}{l}\text { Lipid uptake and inflammatory cytokine } \\
\text { secretion }\end{array}$ & \\
\hline miR-21 & $\begin{array}{l}\text { FABP7, PPAR } \alpha, \text { PTEN, } \\
\text { Bcl-2, PDCD4 }\end{array}$ & $\begin{array}{l}\text { Depression of AP-1, inflammatory response, } \\
\text { proliferation of SMCs, senescence }\end{array}$ & \\
\hline $\operatorname{miR}-221 / 222$ & c-kit, p27, p57 & $\begin{array}{l}\text { Proliferation of SMCs, contractile gene } \\
\text { transcription }\end{array}$ & \\
\hline
\end{tabular}

\section{Circulating miRNAs as a biomarker of heart allograft rejection}

Circulating organ/tissue-specific-enriched miRNAs may indicate direct organ/tissue injury or cell death, and circulating immune-associated miRNAs may serve as sensors of the immune state. Various cellular and immunological mechanisms regulate the process of organ rejection, and emerging evidence indicates that miRNAs play a vital role in these processes (Sarma et al. 2012).

Other studies of heart transplant models demonstrate the differential regulation of miRNAs compared to controls (Wei et al. 2012). MiRNAs have been shown to play a key role in T- and B-cell-mediated rejection and regulatory $\mathrm{T}$-cell activity (Harris et al.
2010, Shan et al. 2011, Feng et al. 2013). Intracellular communication between antigen-presenting cells (APC) such as dendritic cells (DC), macrophages, and B- and T-cells is likely modulated by miRNAs. The differential expression of miR-155 and -221 has been detected as playing an important role in the differentiation of monocytes into immature DC and mature DC at various stages (Martinez-Nunez et al. 2009, Lu et al. 2011).

In a study by Sukma Dewi et al. (2013), significant changes were found in six circulating miRNAs (miR-326, -142-3p, -101, -144, -27, and -424) before, during, and after rejection. All six miRNAs are expressed by immune cells and three of them (miR-326, -142-3p, and -101) have crucial functions in the regulation and maintenance of self-tolerance. A study by Wang et al. 
(2013) found dynamic change in three circulating cardioor skeletal muscle-specific miRNAs (miR-33a/b, and -208a), which may reflect early myocardial injury after heart transplantation in humans. Necrosis and apoptosis of cardiomyocytes after cold ischemia may lead to the release of miRNAs into the blood. Recently, another study identified miRNAs (miR-10a, -31, -92a, and -155) that were differentially expressed for normal and rejecting heart allografts, and also showed that differential serological expression strongly correlated with tissular expression. These circulating miRNAs strongly discriminate patients with allograft rejection from patients without rejection (Duong van Huyen et al. 2014).

\section{Polymorphisms and miRNA}

The miRNA regulome is defined as the compendium of regulatory elements that either regulate miRNA expression (transcriptional control elements and pre-miRNAs) or are regulated by miRNA activity (RNA target sites). Genetic variation in the miRNA regulome can perturb miRNA expression and/or function, potentially contributing to disease development and a wide variety of lipid-related phenotypes (Sethupathy 2013, Obsteter et al. 2015). Advancements in the miRNA field indicate the clear involvement of miRNAs and genetic variations within the miRNA pathway in the progression and prognosis of many diseases, including atherosclerotic cardiovascular diseases. Polymorphisms that may potentially affect miRNA-mediated regulation of cells can be present not only in the 3'UTR of a miRNA target gene, but also in the genes involved in miRNA biogenesis and in pri-, pre-, and mature-miRNA sequences. A polymorphism in processed miRNAs may affect expression of several genes and have serious consequences, whereas a polymorphism in the miRNA target site may be more target- and/or pathway-specific (Mishra and Bertino 2009). Additionally, polymorphisms within miRNA regulatory regions (variations which affect the ability of transcription factors to bind to DNA) have been shown to influence miRNA expression (Luo et al. 2011).

A single nucleotide polymorphism (SNP) rs2910164 in the precursor of miR-146a, a negative regulator of inflammation, has been found to be associated with risk of CAD and ischemic stroke (IS) (Ramkaran et al. 2014, Xiong et al. 2014, Huang et al. 2015). Bao et al. (2015) subsequently verified these relationships in a metaanalysis. Another study analyzed polymorphisms in pre-miRNA sequences (miR-146aC $>\mathrm{G}$ (rs2910164), miR-149T $>$ C (rs2292832), miR-196a2T $>$ C (rs11614913) and $\operatorname{miR}-499 \mathrm{~A}>\mathrm{G} \quad(\mathrm{rs} 3746444)$ ) and found the miR-146aC $>\mathrm{G}$ polymorphism and miR-146aG/-149T/ $-196 \mathrm{a} 2 \mathrm{C} /-499 \mathrm{G}$ allele combination to be significantly associated with IS prevalence (Jeon et al. 2013).

Table 5. DNA polymorphisms within miRNAs and gene target sequences associated with different CVD.

\begin{tabular}{|l|l|l|l|l|}
\hline miRNA & $\begin{array}{l}\text { SNPs within } \\
\text { miRNA gene }\end{array}$ & Target gene & Biological function & Disease \\
\hline miR-146a & rs2910164 & IRAK1; TRAF6 & Negative regulator of inflammation & CAD; IS \\
\hline miR-150 & rs7305605 & MAPK9, IRAK2 & Inflammation and apoptosis pathway & IS \\
\hline miR-200b & rs7549819 & PRKAR2B & Platelet biogenesis and activation & IS \\
\hline miR-4513 & rs2168518 & GOSR2 & $\begin{array}{l}\text { Transport of angiontensin, insulin, leptin between } \\
\text { Golgi compartments }\end{array}$ & CAD \\
\hline niR-499 & rs3746444 & SOX6 & $\begin{array}{l}\text { Affect cardiomyocyte apoptosis via inhibiting } \\
\text { mitochondrial apoptosis pathway }\end{array}$ & CAD \\
\hline miRNA & $\begin{array}{l}\text { SNPs within } \\
\text { 3'UTRs }\end{array}$ & Target gene & Biological function & Disease \\
\hline miR-224 & rs12190287 & TCF21 & $\begin{array}{l}\text { Regulation of coronary artery SMC and cardiac } \\
\text { fibroblast }\end{array}$ & CAD \\
\hline miR-155 & rs5186 & AGTR1 & $\begin{array}{l}\text { Vasoconstriction; cardiac hypertrophy and } \\
\text { remodeling, heart failure, vascular thickening, and } \\
\text { atherosclerosis }\end{array}$ & Hypertension \\
\hline miR-616 & rs3735590 & PON1 & Inhibits oxidation in LDL and HDL & IS \\
\hline miR-149 & rs4846049 & MTHFR & Role in folate and homocysteine metabolism & CAD \\
\hline
\end{tabular}


The CAD-associated polymorphism rs12190287, which resides in the 3'-UTR of TCF21 (a regulator of the formation of coronary artery smooth muscle cells and cardiac fibroblasts), is predicted to alter the seed-binding sequence for miR-224 (Miller et al. 2014). MiR-155 differentially interacts with its polymorphism (rs5186) within the 3' UTR of the human AGTRl gene. MiR-155 downregulates the expression of the 1166A allele only, but not the $1166 \mathrm{C}$ allele, which is associated with hypertension. Rs3735590 C/T within the miR-616 target gene PON1 has been found to be associated with reduced risk of $\mathrm{CAD}$ incidence, and carrying $\mathrm{C}$ alleles are an independent risk factor for CAD (Zhang et al. 2016). DNA polymorphisms within miRNA genes and gene target sequences associated with different CVDs are summarized in Table 5.

It has recently been determined that the expression of certain miRNAs is regulated by DNA methylation, which indicates that several layers of epigenetic mechanisms are involved in the regulation of gene expression (Saito and Jones 2006, Lehmann et al. 2008, Zhu and Fan 2011).

\section{MiRNA databases}

Accurately identifying and cataloguing miRNA targets are crucial in understanding their function. To this end, numerous wet-lab methodologies have been developed, enabling the validation of predicted miRNA interactions or the high-throughput screening and identification of novel miRNA targets (Thomson et al. 2011). Currently available methodologies provide important research tools and are often used complementarily in investigative studies. The most prominent database is miRBase (http://www.mirbase. org/), which was set up to provide official nomenclatures for the miRNA research community. However, it contains limited information on miRNA functional annotations. A few other databases have been developed to focus more on miRNA function. For example, TargetScan (http://www.targetscan.org/vert_71) and PicTar (http:// www.pictar.org) host miRNA targets predicted by different computational algorithms (Wang 2008).

DIANA-TarBase v7.0 (http://www.microrna.gr/ tarbase) is the first database that aims to provide hundreds of thousands of high-quality manually curated experimentally validated miRNA:gene interactions, enhanced with detailed meta-data (Vlachos et al. 2014).

In the miRDB database, miRNA functional annotations are presented with a primary focus on mature miRNAs, which are the functional carriers of miRNA-mediated gene expression regulation. In addition, a wiki-editing interface has been established to allow anyone with internet access to make contributions on miRNA functional annotation (Wang 2008). All data stored in miRDB are freely accessible at http://mirdb.org.

MiRandola is the first comprehensive database of extracellular circulating miRNAs. The database is a useful reference tool for anyone investigating the role of extracellular miRNAs as non-invasive biomarkers and their physiological function and involvement in disease (Russo et al. 2012). The current version of miRandola focuses on human circulating miRNAs. MiRandola is available online at http://mirandola.iit.cnr.it/index.php.

\section{Factors interfering with analysis of circulating miRNAs}

\section{Pre-profiling effects}

Variability in the results of studies identifying miRNA biomarkers for the same disease may be attributed to pre-profiling sources, such as sample collection methods, patient lifestyle, and drug treatment. Analytical differences, such as the isolation methods of miRNAs, quantification platforms, and normalization methods, may also contribute to the variability of results (Zampetaki et al. 2012, MacLellan et al. 2014).

\section{Hemolysis}

Some studies have previously described that the majority of miRNAs found in serum or plasma are also present in blood cells. Hemolysis caused during sample collection or processing may affect the miRNA profile of the sample. Due to their presence in blood cells, the most affected miRNAs are miR-451a, -16, -24, -15, and -223 (Blondal et al. 2012, Kirschner et al. 2013).

\section{Lifestyle}

MiRNA expression in healthy subjects is altered as a result of fasting, dietary lipid intake, smoking, or regular exercise (Kroh et al. 2010).

\section{Obesity}

Only a few studies have investigated circulating miRNA levels as potential biomarkers for obesity in humans. Circulating miRNAs are commonly deregulated in severe obesity. Specific circulating miRNAs are significantly regulated in pre-pubertal obesity, including 
decreased miR-221 and -28-3p and increased concentrations of miR-486-5p, -486-3p, -142-3p, -130b, and $-423-5 p$ detected in plasma. The circulating concentrations of these miRNAs are significantly associated with body mass index and other measures of obesity (Prats-Puig et al. 2013). Elevated circulating miR-122, a liver-specific miRNA involved in cholesterol homeostasis, is positively associated with obesity and insulin resistance in young adults (Wang et al. 2015). A significant increase of miR-140-5p, -142-3p, and -222 and decreased levels of miR-532-5p, $-125 b,-130 b,-221$, $-15 a,-423-5 p$, and $-520 c-3 p$ in morbidly obese patients have also been found. Weight loss-induced changes in this profile and in one study of in silico targets support this observation and suggest a potential mechanistic relevance (Ortega et al. 2013).

\section{Smoking}

Studies focusing on changes in the miRNA landscape in humans and animals exposed to cigarette smoke are fairly new and, therefore, in vivo studies are limited. Plasma levels of miR-223 and -126 affected by tobacco smoke exposure have been reported (Takahashi et al. 2013, Badrnya et al. 2014).

\section{Physical activity}

A few studies have shown that increased physical activity is associated with altered levels of circulating miRNAs. Altered expression of miRNAs, not only muscle-enriched miRNAs (miR-1 and $-133 \mathrm{a} / \mathrm{b}$ ) but also liver-specific miRNAs (miR-143 and -145), has been shown to be dynamically regulated in response to both acute and chronic exercise interventions (Baggish et al. 2011). One study demonstrated that low maximal aerobic oxygen consumption is associated with high expression levels of three different miRNAs (miR-21, -210, and -222) (Bye et al. 2013). Most miRNAs altered due to exercise are involved in lipid metabolism.

\section{Comparing serum and plasma miRNA levels}

Although similar levels of miRNAs in serum and plasma have been previously reported (Blondal et al. 2013), inconsistencies between miRNA levels in both serum and plasma have also been found (Huang et al. 2013). It has been notably observed that thrombocyteassociated miRNAs in particular are found in much higher concentrations in plasma than in serum. Since thrombocyte-derived miRNAs such as miR-126, -223, and -197 seem to play a significant role in the prognosis of future cardiovascular events (especially in the field of miRNA-based diagnostics of CAD), standardized methods are needed for future clinical miRNA quantification studies (Schulte and Zeller 2015).

\section{Biological aspects}

Various miRNAs are known to exert key roles in ageing, and other miRNAs are encoded on sex chromosomes (Boon et al. 2013). These facts suggest that a relevant portion of human miRNA profiles depends on the age and sex distribution of samples. In one study, the miRNAs most strongly affected by age were identified as miR-1284, -93-3p, -1262, -34a, and -145, while the miRNAs most influenced by sex were miR-219a, $-548 \mathrm{c}$, and -130a (Meder et al. 2014).

\section{Drug treatment}

Heparin, commonly used as an anticoagulant in cardiovascular diagnostics and interventions, inhibits RNA quantification by interfering with the DNA polymerases used in the quantitative PCR reaction. Moreover, heparin has also been described as strongly interfering with the detection of recombinant cel-miR-39 when spiked into samples for normalization purposes (Boeckel et al. 2012, Kim et al. 2012). Cel-miR-39 may be used for normalization to counteract the possible unfavorable influence of heparin treatment, which leads to distorted miRNA analysis results. More accurate results are produced when using a form of normalization that takes the mean of at least three circulating miRNAs stably expressed in plasma.

Quantification of miRNA levels altered in CAD may also be influenced by the intake of medications such as statins and ACE inhibitors (Fichtlscherer et al. 2010, Weber et al. 2011). Antiplatelet aspirin treatment has been shown to influence plasma miR-126 in subjects with T2DM (de Boer et al. 2013). MiR-221/222 expression was downregulated and a number of endothelial progenitor cells increased in one group of CAD patients after one year under statin therapy (Minami et al. 2009). In another pilot study, statins used for lipid-lowering therapy decreased inflammation-associated miRNAs (miR-106b, -21, -25, -451, and -92a) in patients with unstable angina (Zhang et al. 2015).

\section{Conclusions}

The emergence of miRNAs as key regulators of cholesterol metabolism and potentially also vascular 
function has attracted much interest over the years, not only from a physiological standpoint but also from a clinical perspective, as many miRNAs have been shown to be biomarkers of dyslipidemia and regulators of the mechanisms leading to atherosclerotic CVD. Ascertaining the relative contribution of each non-coding RNA in governing the initiation and development of the atherosclerotic process may shed further light on the influence of miRNAs on target-gene regulation and help to evaluate the therapeutic potential of manipulating miRNA expression in the treatment of cardiometabolic disorders. As miRNAs may represent therapeutic targets in atherosclerosis, it is therefore of utmost importance to study the mechanisms (e.g. delivery, target, and recognition machinery) that sort miRNA into exosomes. Clearly, the methods of collection and preparation used can significantly influence results and must be taken into account when evaluating miRNAs as circulating biomarkers of pathological processes.

\section{Conflict of Interest}

There is no conflict of interest.

\section{Acknowledgements}

The study was supported by project 00023001 (Ministry of Health, Czech Republic) for the development of research organizations (Institute for Clinical and Experimental Medicine, Prague, Czech Republic) institutional support and by the projects of the Ministry of Health of the Czech Republic - grants no. 15-28895A and 17-28882A. All rights reserved.

\section{References}

AL-KAFAJI G, AL-MAHROOS G, ABDULLA AL-MUHTARESH H, SABRY MA, ABDUL-RAZZAK R, SALEM AH: Circulating endothelium-enriched microRNA-126 as a potential biomarker for coronary artery disease in type 2 diabetes mellitus patients. Biomarkers 11: 1-11, 2016.

ASGEIRSDOTTIR SA, VAN SOLINGEN C, MURNIATI NF, ZWIERS PJ, HEERINGA P, VAN MEURS M, SATCHELL SC, SALEEM MA, MATHIESON PW, BANAS B, KAMPS JA, RABELINK TJ, VAN ZONNEVELD AJ, MOLEMA G: MicroRNA-126 contributes to renal macrovascular heterogeneity of VCAM-1 protein expression in acute inflammation. Am J Physiol Renal Physiol 302: F1630-F1639, 2012.

BADRNYA S, BAUMGARTNER R, ASSINGER A: Smoking alters circulating plasma microvesicle pattern and microRNA signatures. Thromb Haemost 112: 128-136, 2014.

BAGGISH AL, HALE A, WEINER RB, LEWIS GD, SYSTROM D, WANG F, WANG TJ, CHAN SY: Dynamic regulation of circulating microRNA during acute exhaustive exercise and sustained aerobic exercise training. J Physiol 15: 3983-3994, 2011.

BAO MH, XIAO Y, ZHANG QS, LUO HQ, LUO J, ZHAO J, LI GY, ZENG J, LI JM: Meta-analysis of miR-146a polymorphisms association with coronary artery diseases and ischemic stroke. Int J Mol Sci 16: 14305-14317, 2015.

BLONDAL T, JENSBY NIELSEN S, BAKER A, ANDREASEN D, MOURITZEN P, WRANG TEILUM M, DAHLSVEEN IK: Assessing sample and miRNA profile quality in serum and plasma or other biofluids. Methods 59: S1-S6, 2012.

BOECKEL JN, THOME CE, LEISTNER D, ZEIHER AM, FICHTLSCHERER S, DIMMELER S: Heparin selectively affects the quantification of microRNAs in human blood samples. Clin Chem 59: 1125-1127, 2013.

BOON RA, IEKUSHI K, LECHNER S, SEEGER T, FISCHER A, HEYDT S, KALUZA D, TRÉGUER K, CARMONA G, BONAUER A, HORREVOETS AJ, DIDIER N, GIRMATSION Z, BILICZKI P, EHRLICH JR, KATUS HA, MÜLLER OJ, POTENTE M, ZEIHER AM, HERMEKING H, DIMMELER S: MicroRNA-34a regulates cardiac ageing and function. Nature 495: 107-110, 2013.

BROWN MS, GOLDSTEIN JL: The SREBP pathway: regulation of cholesterol metabolism by proteolysis of a membrane-bound transcription factor. Cell 89: 331-340, 1997.

BYE A, ROSJO H, ASPENES ST, CONDORELLI G, OMLAND T, WISLOFF U: Circulating microRNAs and aerobic fitness-the HUNT study. PLoS One 8:e57496, 2013.

CALEY DP, PINK RC, TRUJILLANO D, CARTER DR: Long noncoding RNAs, chromatin, and development. Sci World J 10: 90-102, 2010. 
CHEN JF, MANDEL EM, THOMSON JM, WU Q, CALLIS TE, HAMMOND SM, CONLON FL, WANG DZ: The role of microRNA-1 and microRNA-133 in skeletal muscle proliferation and differentiation. Nat Genet 38: 228-233, 2006.

CHEN KC, WANG YS, HU CY, CHANG WC, LIAO YC, DAI CY, JUO SH: OxLDL up-regulates microRNA-29b, leading to epigenetic modifications of MMP-2/MMP-9 genes: a novel mechanism for cardiovascular diseases. FASEB J 25: 1718-1728, 2011.

CHEN T, HUANG Z, WANG L, WANG Y, WU F, MENG S, WANG C: MicroRNA-125a-5p partly regulates the inflammatory response, lipid uptake, and ORP9 expression in oxLDL-stimulated monocyte/macrophages. Cardiovasc Res 83: 131-139, 2009.

CHIEN HY, CHEN CY, CHIU YH, LIN YC, LI WC: Differential microRNA profiles predict diabetic nephropathy progression in Taiwan. Int J Med Sci 13: 457-465, 2016.

CORSTEN MF, DENNERT R, JOCHEMS S, KUZNETSOVA T, DEVAUX Y, HOFSTRA L, WAGNER DR, STAESSEN JA, HEYMANS S, SCHROEN B: Circulating microRNA-208b and microRNA-499 reflect myocardial damage in cardiovascular disease. Circ Cardiovasc Genet 3: 499-506, 2010.

D'ALESSANDRA Y, DEVANNA P, LIMANA F, STRAINO S, DI CARLO A, BRAMBILLA PG, RUBINO M, CARENA MC, SPAZZAFUMO L, DE SIMONE M, MICHELI B, BIGLIOLI P, ACHILLI F, MARTELLI F, MAGGIOLINI S, MAGGIOLINI S, MARENZI G, POMPILIO G, CAPOGROSSI MC: Circulating microRNAs are new and sensitive biomarkers of myocardial infarction. Eur Heart J 31: 2765-2773, 2010.

DAWSON K, WAKILI R, ORDÖG B, CLAUSS S, CHEN Y, IWASAKI Y, VOIGT N, QI XY, SINNER MF, DOBREV D, KÄ̈̈B S, NATTEL S: MicroRNA29: a mechanistic contributor and potential biomarker in atrial fibrillation. Circulation 127: 1466-1475, 2013.

DE BOER HC, VAN SOLINGEN C, PRINS J, DUIJS JM, HUISMAN MV, RABELINK TJ, VAN ZONNEVELD AJ: Aspirin treatment hampers the use of plasma microRNA-126 as a biomarker for the progression of vascular disease. Eur Heart J 34: 3451-3457, 2013.

DENTELLI P, ROSSO A, ORSO F, OLGASI C, TAVERNA D, BRIZZI MF: MicroRNA-222 controls neovascularization by regulating signal transducer and activator of transcription 5A expression. Arterioscler Thromb Vasc Biol 30: 1562-1568, 2010.

DUBÉ JB, HEGELE RA: Genetics 100 for cardiologists: basics of genome-wide association studies. Can J Cardiol 29: 10-17, 2013.

DUONG VAN HUYEN JP, TIBLE M, GAY A, GUILLEMAIN R, AUBERT O, VARNOUS S, ISERIN F, ROUVIER P, FRANÇOIS A, VERNEREY D, LOYER X, LEPRINCE P, EMPANA JP, BRUNEVAL P, LOUPY A, JOUVEN X: MicroRNAs as non-invasive biomarkers of heart transplant rejection. Eur Heart J 35: 3194-3202, 2014.

ELMEN J, LINDOW M, SCHÜTZ S, LAWRENCE M, PETRI A, OBAD S, LINDHOLM M, HEDTJÄRN M, HANSEN HF, BERGER U, GULLANS S, KEARNEY P, SARNOW P, STRAARUP EM, KAUPPINEN S: LNA-mediated microRNA silencing in non-human primates. Nature 452: 896-899, 2008.

FANG Y, DAVIES PF: Site-specific microRNA-92a regulation of Kruppel-like factors 4 and 2 in atherosusceptible endothelium. Arterioscler Thromb Vasc Biol 32: 979-987, 2012.

FANG Y, SHI C, MANDUCHI E, CIVELEK M, DAVIES PF: MicroRNA-10a regulation of proinflammatory phenotype in athero-susceptible endothelium in vivo and in vitro. Proc Natl Acad Sci USA 107: 13450-13455, 2010.

FEINBERG MW, MOORE KJ: MicroRNA regulation of atherosclerosis. Circ Res 118: 703-720, 2016.

FENG J, XING W, XIE L: Regulatory roles of microRNAs in diabetes. Int J Mol Sci 17: E1729, 2016.

FENG Z, XIA Y, ZHANG M, ZHENG J: MicroRNA-155 regulates T cell proliferation through targeting GSK3 $\beta$ in cardiac allograft rejection in a murine transplantation model. Cell Immunol 281: 141-149, 2013.

FICHTLSCHERER S, DE RS, FOX H, SCHWIETZ T, FISCHER A, LIEBETRAU C, WEBER M, HAMM CW, ROXE T, MULLER-ARDOGAN M, BONAUER A, ZEIHER AM, DIMMELER S: Circulating microRNAs in patients with coronary artery disease. Circ Res 107: 677-684, 2010.

FUKUSHIMA Y, NAKANISHI M, NONOGI H, GOTO Y, IWAI N: Assessment of plasma miRNAs in congestive heart failure. Circul J 75: 336-340, 2011. 
GOETTSCH C, RAUNER M, PACYNA N, HEMPEL U, BORNSTEIN SR, HOFBAUER LC: miR-125b regulates calcification of vascular smooth muscle cells. Am J Pathol 179: 1594-1600, 2011.

GOREN Y, KUSHNIR M, ZAFRIR B, TABAK S, LEWIS BS, AMIR O: Serum levels of microRNAs in patients with heart failure. Eur J Heart Fail 14: 147-154, 2012.

GOREN Y, MEIRI E, HOGAN C, MITCHELL H, LEBANONY D, SALMAN N, SCHLIAMSER JE, AMIR O: Relation of reduced expression of MiR-150 in platelets to atrial fibrillation in patients with chronic systolic heart failure. Am J Cardiol 113: 976-981, 2014.

GUO M, MAO X, JI Q, LANG M, LI S, PENG Y, ZHOU W, XIONG B, ZENG Q: miR-146a in PBMCs modulates Th1 function in patients with acute coronary syndrome. Immunol Cell Biol 88: 555-564, 2010.

HARRIS A, KRAMS SM, MARTINEZ OM: MicroRNAs as immune regulators: implications for transplantation. Am $J$ Transplant 10: 713-719, 2010.

HUANG RS, HU GQ, LIN B, LIN ZY, SUN CC: MicroRNA-155 silencing enhances inflammatory response and lipid uptake in oxidized low-density lipoprotein-stimulated human THP-1 macrophages. J Invest Med 58: 961-967, 2010.

HUANG S, ZHOU S, ZHANG Y, LV Z, LI S, XIE C, KE Y, DENG P, GENG Y, ZHANG Q, CHU X, YI Z, ZHANG $\mathrm{Y}, \mathrm{WU}$ T, CHENG J: Association of the genetic polymorphisms in pre-microRNAs with risk of ischemic stroke in a Chinese population. PLoS One 10: e117007, 2015.

HUANG X, LIANG M, DITTMAR R, WANG L: Extracellular microRNAs in urologic malignancies: chances and challenges. Int J Mol Sci 14: 14785-14799, 2013.

HUBÁČEK JA: Apolipoprotein A5 fifteen years anniversary: Lessons from genetic epidemiology. Gene 592: 193-199, 2016.

ITO T, YAGI S, YAMAKUCHI M: MicroRNA-34a regulation of endothelial senescence. Biochem Biophys Res Commun 398: 735-740, 2010.

IWASAKI YW, SIOMI MC, SIOMI H: PIWI-Interacting RNA: its biogenesis and functions. Annu Rev Biochem 84: 405-433, 2015.

JEON YJ, KIM OJ, KIM SY, OH SH, OH D, KIM OJ, SHIN BS, KIM NK: Association of the miR-146a, miR-149, miR-196a2, and miR-499 polymorphisms with ischemic stroke and silent brain infarction risk. Arterioscler Thromb Vasc Biol 33: 420-430, 2013.

KAIKKONEN MU, LAM MT, GLASS CK: Non-coding RNAs as regulators of gene expression and epigenetics. Cardiovasc Res 90: 430-440, 2011.

KATHIRESAN S, MELANDER O, GUIDUCCI C, SURTI A, BURTT NP, RIEDER MJ, COOPER GM, ROOS C, VOIGHT BF, HAVULINNA AS, WAHLSTRAND B, HEDNER T, CORELLA D, TAI ES, ORDOVAS JM, ET AL.: Six new loci associated with blood low-density lipoprotein cholesterol, high-density lipoprotein cholesterol or triglycerides in humans. Nat Genet 40: 189-197, 2008. Erratum in: Nat Genet 40: 1384, 2008.

KAUDEWITZ D, ZAMPETAKI A, MAYR M: MicroRNA biomarkers for coronary artery disease? Curr Atheroscler 17: 70, 2015.

KIM DJ, LINNSTAEDT S, PALMA J, PARK JC, NTRIVALAS E, KWAK-KIM JY, GILMAN-SACHS A, BEAMAN K, HASTINGS ML, MARTIN JN, DUELLI DM: Plasma components affect accuracy of circulating cancerrelated microRNA quantitation. J Mol Diagn 14: 71-80, 2012.

KIM JB, SPOTTS GD, HALVORSEN YD, SHIH HM, ELLENBERGER T, TOWLE HC, SPIEGELMAN BM: Dual DNA binding specificity of ADD1/SREBP1 controlled by a single amino acid in the basic helix-loop-helix domain. Mol Cell Biol 15: 2582-2588, 1995.

KIRSCHNER MB, EDELMAN JJ, KAO SC, VALLELY MP, VAN ZANDWIJK N, REID G: The impact of hemolysis on cell-free microRNA biomarkers. Front Genet 4: 94, 2013.

KROH EM, PARKIN RK, MITCHELL PS, TEWARI M: Analysis of circulating microRNA biomarkers in plasma and serum using quantitative reverse transcription-PCR (qRT-PCR). Methods 50: 298-301, 2010.

KUMARSWAMY R, THUM T: Non-coding RNAs in cardiac remodeling and heart failure. Circ Res 113: 676-689, 2013.

KUNEŠ J, VANĚČKOVÁ I, MIKULÁŠKOVÁ B, BEHULIAK M, MALETÍNSKÁ L, ZICHA J: Epigenetics and a new look on metabolic syndrome. Physiol Res 64: 611-620, 2015. 
KURA B, YIN C, FRIMMEL K, KRIZAK J, OKRUHLICOVA L, KUKREJA RC, SLEZAK J: Changes of microRNA-1, -15b and -21 levels in irradiated rat hearts after treatment with potentially radioprotective drugs. Physiol Res 65 (Suppl 1): S129-S137, 2016.

LAGOS-QUINTANA M, RAUHUT R, YALCIN A, MEYER J, LENDECKEL W, TUSCHL T: Identification of tissue-specific microRNAs from mouse. Curr Biol 12: 735-739, 2002.

LANDGRAF P, RUSU M, SHERIDAN R, SEWER A, IOVINO N, ARAVIN A, PFEFFER S, RICE A, KAMPHORST AO, LANDTHALER M, LIN C, SOCCI ND, HERMIDA L, FULCI V, CHIARETTI S, ET AL.: A mammalian microRNA expression atlas based on small RNA library sequencing. Cell 129: 1401-1414, 2007.

LEEPER NJ, RAIESDANA A, KOJIMA Y, CHUN HJ, AZUMA J, MAEGDEFESSEL L, KUNDU RK, QUERTERMOUS T, TSAO PS, SPIN JM: MicroRNA-26a is a novel regulator of vascular smooth muscle cell function. J Cell Physiol 226: 1035-1043, 2011.

LEHMANN U, HASEMEIER B, CHRISTGEN M, MÜLLER M, RÖMERMANN D, LÄNGER F, KREIPE H: Epigenetic inactivation of microRNA gene hsa-mir-9-1 in human breast cancer. J Pathol 214: 17-24, 2008.

LI Z, HASSAN MQ, JAFFERJI M, AQEILAN RI, GARZON R, CROCE CM, VAN WIJNEN AJ, STEIN JL, STEIN GS, LIAN JB: Biological functions of miR-29b contribute to positive regulation of osteoblast differentiation. J Biol Chem 284: 15676-15684, 2009.

LIN Y, LIU X, CHENG Y, YANG J, HUO Y, ZHANG C: Involvement of MicroRNAs in hydrogen peroxide-mediated gene regulation and cellular injury response in vascular smooth muscle cells. J Biol Chem 284: 7903-7913, 2009.

LIU X, CHENG Y, YANG J, XU L, ZHANG C: Cell-specific effects of miR-221/222 in vessels: molecular mechanism and therapeutic application. J Mol Cell Cardiol 52: 245-255, 2012.

LIU Z, ZHOU C, LIU Y, WANG S, YE P, MIAO X, XIA J: The expression levels of plasma micoRNAs in atrial fibrillation patients. PLoS One 7: e44906, 2012.

LOVREN F, PAN Y, QUAN A, SINGH KK, SHUKLA PC, GUPTA N, STEER BM, INGRAM AJ, GUPTA M, AL-OMRAN M, TEOH H, MARSDEN PA, VERMA S: MicroRNA-145 targeted therapy reduces atherosclerosis. Circulation 126 (Suppl 1): S81-S90, 2012.

LU C, HUANG X, ZHANG X, ROENSCH K, CAO Q, NAKAYAMA KI, BLAZAR BR, ZENG Y, ZHOU X: miR-221 and miR-155 regulate human dendritic cell development, apoptosis, and IL-12 production through targeting of p27kip1, KPC1, and SOCS-1. Blood 117: 4293-4303, 2011.

LUO X, YANG W, YE DQ, CUI H, ZHANG Y, HIRANKARN N, QIAN X, TANG Y, LAU YL, DE VRIES N, TAK PP, TSAO BP, SHEN N: A functional variant in microRNA-146a promoter modulates its expression and confers disease risk for systemic lupus erythematosus. PLoS Genet 7: e1002128, 2011.

MACFARLANE LA, MURPHY PR: MicroRNA: biogenesis, function and role in cancer. Curr Genomics 11: 537-561, 2010.

MACLELLAN SA, MACAULAY C, LAM S, GARNIS C: Pre-profiling factors influencing serum microRNA levels. BMC Clin Pathol 14: 27, 2014.

MADRIGAL-MATUTE J, ROTLLAN N, ARANDA JF, FERNANDÉZ-HERNANDO C: MicroRNA and atherosclerosis. Curr Atheroscler Rep 15: 322-335, 2013.

MARTINEZ-NUNEZ RT, LOUAFI F, FRIEDMANN PS, SANCHEZ-ELSNER T: MicroRNA-155 modulates the pathogen binding ability of dendritic cells (DCs) by down-regulation of DC-specific intercellular adhesion molecule-3 grabbing non-integrin (DC-SIGN). J Biol Chem 284: 16334-16342, 2009.

MEDER B, BACKES C, HAAS J, LEIDINGER P, STÄHLER C, GROSSMANN T, VOGEL B, FRESE K, GIANNITSIS E, KATUS HA, MEESE E, KELLER A: Influence of the confounding factors age and sex on microRNA profiles from peripheral blood. Clin Chem 60: 1200-1208, 2014.

MENGHINI R, CASAGRANDE V, CARDELLINI M, MARTELLI E, TERRINONI A, AMATI F, VASA-NICOTERA M, IPPOLITI A, NOVELLI G, MELINO G, LAURO R, FEDERICI M: MicroRNA 217 modulates endothelial cell senescence via silent information regulator 1. Circulation 120: 1524-1532, 2009.

MENGHINI R, STÖHR R, FEDERICI M: MicroRNAs in vascular aging and atherosclerosis. Ageing Res Rev 17: 68-78, 2014. 
MILLER CL, HAAS U, DIAZ R, LEEPER NJ, KUNDU RK, PATLOLLA B, ASSIMES TL, KAISER FJ, PERISIC L, HEDIN U, MAEGDEFESSEL L, SCHUNKERT H, ERDMANN J, QUERTERMOUS T, SCZAKIEL G: Coronary heart disease-associated variation in TCF21 disrupts a miR-224 binding site and miRNA-mediated regulation. PLoS Genet 10: e1004263, 2014.

MINAMI Y, SATOH M, MAESAWA C, TAKAHASHI Y, TABUCHI T, ITOH T, NAKAMURA M: Effect of atorvastatin on microRNA 221/222 expression in endothelial progenitor cells obtained from patients with coronary artery disease. Eur J Clin Invest 39: 359-367, 2009.

MISHRA PJ, BERTINO JR: MicroRNA polymorphisms: the future of pharmacogenomics, molecular epidemiology and individualized medicine. Pharmacogenomics 10: 399-416, 2009.

MUKA T, KOROMANI F, PORTILLA E, O'CONNOR A, BRAMER WM, TROUP J, CHOWDHURY R, DEHGHAN A, FRANCO OH: The role of epigenetic modifications in cardiovascular disease: a systematic review. Int J Cardiol 212: 174-183, 2016.

OBSTETER J, DOVC P, KUNEJ T: Genetic variability of microRNA regulome in human. Mol Genet Genomic Med 3: 30-39, 2015.

ORTEGA FJ, MERCADER JM, CATALÁN V, MORENO-NAVARRETE JM, PUEYO N, SABATER M, GÓMEZAMBROSI J, ANGLADA R, FERNÁNDEZ-FORMOSO JA, RICART W, FRÜHBECK G, FERNÁNDEZREAL JM: Targeting the circulating microRNA signature of obesity. Clin Chem 59: 781-792, 2013.

PASMANT E, SABBAGH A, VIDAUD M, BIĖCHE I: ANRIL, a long, noncoding RNA, is an unexpected major hotspot in GWAS. FASEB J 25: 444-448, 2011.

PRATS-PUIG A, ORTEGA FJ, MERCADER JM, MORENO-NAVARRETE JM, MORENO M, BONET N, RICART W, LÓPEZ-BERMEJO A, FERNÁNDEZ-REAL JM: Changes in circulating microRNAs are associated with childhood obesity. J Clin Endocrinol Metab 98: E1655-E1660, 2013.

RAMKARAN P, KHAN S, PHULUKDAREE A, MOODLEY D, CHUTURGOON AA: miR-146a polymorphism influences levels of miR-146a, IRAK-1, and TRAF-6 in young patients with coronary artery disease. Cell Biochem Biophys 68: 259-266, 2014.

RAWAL S, MANNING P, KATARE R: Cardiovascular microRNAs: as modulators and diagnostic biomarkers of diabetic heart disease. Cardiovasc Diabetol 13: 44, 2014.

RAYNER KJ, SHEEDY FJ, ESAU CC, HUSSAIN FN, TEMEL RE, PARATHATH S, VAN GILS JM, RAYNER AJ, CHANG AN, SUAREZ Y, FERNANDEZ-HERNANDO C, FISHER EA, MOORE KJ: Antagonism of miR-33 in mice promotes reverse cholesterol transport and regression of atherosclerosis. J Clin Invest 121: 2921-2931, 2011.

ROBERTS R, STEWART AF: 9p21 and the genetic revolution for coronary artery disease. Clin Chem 58: 104-112, 2012.

RONCARATI R, VIVIANI ANSELMI C, LOSI MA, PAPA L, CAVARRETTA E, DA COSTA MARTINS P, CONTALDI C, SACCANI JOTTI G, FRANZONE A, GALASTRI L, LATRONICO MV, IMBRIACO M, ESPOSITO G, DE WINDT L, BETOCCHI S, CONDORELLI G: Circulating miR-29a, among other up-regulated microRNAs, is the only biomarker for both hypertrophy and fibrosis in patients with hypertrophic cardiomyopathy. J Am Coll Cardiol 63: 920-927, 2014.

RUSSO F, Di BELLA S, NIGITA G, MACCA V, LAGANA A, GIUGNO R, PULVIRENTI A, FERRO A: miRandola: extracellular circulating microRNAs database. PLoS One 7: e47786, 2012.

RUSSO F, DI BELLA S, BONNICI V, LAGANÀ A, RAINALDI G, PELLEGRINI M, PULVIRENTI A, GIUGNO R, FERRO A: A knowledge base for the discovery of function, diagnostic potential and drug effects on cellular and extracellular miRNAs. BMC Genomics 15 (Suppl 3): S4, 2014.

SAITO Y, JONES P: Epigenetic activation of tumor suppressor microRNAs in human cancer cells. Cell Cycle 5: 2220-2222, 2006.

SARMA NJ, TIRIVEEDHI V, RAMACHANDRAN S, CRIPPIN J, CHAPMAN W, MOHANAKUMAR T: Modulation of immune responses following solid organ transplantation by microRNA. Exp Mol Pathol 93: 378-385, 2012.

SCHULTE C, ZELLER T: microRNA-based diagnostics and therapy in cardiovascular disease - summing up the facts. Cardiovasc Diagn Ther 5: 17-36, 2015. 
SETHUPATHY PJ: Needles in the genetic haystack of lipid disorders: single nucleotide polymorphisms in the microRNA regulome. Lipid Res 54: 1168-1173, 2013.

SHAN J, FENG L, LUO L, WU W, LI C, LI S, LI Y: MicroRNAs: potential biomarker in organ transplantation. Transplant Immunol 24: 210-215, 2011.

SUAREZ Y, FERNÁNDEZ-HERNANDO C, YU J, GERBER SA, HARRISON KD, POBER JS, IRUELA-ARISPE ML, MERKENSCHLAGER M, SESSA WC: Dicer-dependent endothelial microRNAs are necessary for postnatal angiogenesis. Proc Natl Acad Sci USA 105: 14082-14087, 2008.

SUAREZ Y, WANG C, MANES TD, POBER JS: Cutting edge: TNF-induced microRNAs regulate TNF-induced expression of E-selectin and intercellular adhesion molecule-1 on human endothelial cells: feedback control of inflammation. J Immunol 184: 21-25, 2010.

SUKMA DEWI I, TORNGREN K, GIDLÖF O, KORNHALL B, OHMAN J: Altered serum miRNA profiles during acute rejection after heart transplantation: potential for non-invasive allograft surveillance. $J$ Heart Lung Transplant 32: 463-466, 2013.

SUN HX, ZENG DY, LI RT, PANG RP, YANG H, HU YL, ZHANG Q, JIANG Y, HUANG LY, TANG YB, YAN GJ, ZHOU JG: Essential role of microRNA-155 in regulating endothelium dependent vasorelaxation by targeting endothelial nitric oxide synthase. Hypertension 60: 1407-1414, 2012.

SUN X, ICLI B, WARA AK, BELKIN N, HE S, KOBZIK L, HUNNINGHAKE GM, VERA MP; MICU REGISTRY, BLACKWELL TS, BARON RM, FEINBERG MW: MicroRNA-181b regulates NF-kappaB-mediated vascular inflammation. J Clin Invest 122: 1973-1990, 2012.

TAKAHASHI K, YOKOTA S, TATSUMI N, FUKAMI T, YOKOI T, NAKAJIMA M: Cigarette smoking substantially alters plasma microRNA profiles in healthy subjects. Toxicol Appl Pharmacol 272: 154-160, 2013.

THOMSON DW, BRACKEN CP, GOODALL GJ: Experimental strategies for microRNA target identification. Nucl Acids Res 39: 6845-6853, 2011.

THUM T: Facts and updates about cardiovascular non-coding RNAs in heart failure. ESC Heart Fail 2: 108-111, 2015.

TURCHINOVICH A, WEIZ L, BURWINKEL B: Extracellular miRNAs: the mystery of their origin and function. Trends Biochem Sci 37: 460-465, 2012.

UCAR A, GUPTA SK, FIEDLER J, ERIKCI E, KARDASINSKI M, BATKAI S, DANGWAL S, KUMARSWAMY R, BANG C, HOLZMANN A, REMKE J, CAPRIO M, JENTZSCH C, ENGELHARDT S, GEISENDORF S, ET AL.: The miRNA-212/132 family regulates both cardiac hypertrophy and cardiomyocyte autophagy. Nat Commun 3: 1078, 2012.

UDALI S, GUARINI P, MORUZZI S, CHOI SW, FRISO S: Cardiovascular epigenetics: from DNA methylation to microRNAs. Mol Aspects Med 34: 883-901, 2013.

VASA-NICOTERA M, CHEN H, TUCCI P, YANG AL, SAINTIGNY G, MENGHINI R, MAHÈ C, AGOSTINI M, KNIGHT RA, MELINO G, FEDERICI M: miR-146a is modulated in human endothelial cell with aging. Atherosclerosis 217: 326-330, 2011.

VLACHOS IS, PARASKEVOPOULOU MD, KARAGKOUNI D, GEORGAKILAS G, VERGOULIS T, KANELLOS I, ANASTASOPOULOS I-L, MANIOU S, KARATHANOU K, KALFAKAKOU D, FEVGAS A, DALAMAGAS T, HATZIGEORGIOU AG: DIANA-TarBase v7.0: indexing more than half a million experimentally supported miRNA:mRNA interactions. Nucl Acids Res 43: D153-D159, 2014.

WANG X: miRDB: a microRNA target prediction and functional annotation database with a wiki interface. RNA 14: 1012-1017, 2008.

WANG E, NIE Y, ZHAO Q, WANG W, HUANG J, LIAO Z, ZHANG H, HU S, ZHENG Z: Circulating miRNAs reflect early myocardial injury and recovery after heart transplantation. J Cardiothorac Surg 8: 165, 2013.

WANG GK, ZHU JQ, ZHANG JT, LI Q, LI Y, HE J, QIN YW, JING Q: Circulating microRNA: a novel potential biomarker for early diagnosis of acute myocardial infarction in humans. Eur Heart J 31: 659-666, 2010.

WANG KJ, ZHAO X, LIU YZ, ZENG QT, MAO XB, LI SN, ZHANG M, JIANG C, ZHOU Y, QIAN C, FENG KG, GUAN HQ, TANG TT, CHENG X, CHEN ZJ: Circulating MiR-19b-3p, MiR-134-5p and MiR-186-5p are promising novel biomarkers for early diagnosis of acute myocardial infarction. Cell Physiol Biochem 38: 1015-1029, 2016. 
WANG R, HONG J, CAO Y, SHI J, GU W, NING G, ZHANG Y, WANG W: Elevated circulating microRNA-122 is associated with obesity and insulin resistance in young adults. Eur J Endocrinol 172: 291-300, 2015.

WEBER M, BAKER MB, PATEL RS, QUYYUMI AA, BAO G, SEARLES CD: MicroRNA expression profile in CAD patients and the impact of ACEI/ARB. Cardiol Res Pract 2011: 532915, 2011.

WEI L, WANG M, QU X, MAH A, XIONG X, HARRIS AG, PHILLIPS LK, MARTINEZ OM, KRAMS SM: Differential expression of microRNAs during allograft rejection. Am J Transplant 12: 1113-1123, 2012.

WILLIAMS AE, LARNER-SVENSSON H, PERRY MM, CAMPBELL GA, HERRICK SE, ADCOCK IM, ERJEFALT JS, CHUNG KF, LINDSAY MA: MicroRNA expression profiling in mild asthmatic human airways and effect of corticosteroid therapy. PLoS One 4: e5889, 2009.

WU W, XIAO H, LAGUNA-FERNANDEZ A, VILLARREAL G JR, WANG KC, GEARY GG, ZHANG Y, WANG WC, HUANG HD, ZHOU J, LI YS, CHIEN S, GARCIA-CARDENA G, SHYY JY: Flow-dependent regulation of Kruppel-like factor 2 is mediated by microRNA-92a. Circulation 124: 633-641, 2011.

XIONG XD, CHO M, CAI XP, CHENG J, JING X, CEN JM, LIU X, YANG XL, SUH Y: A common variant in pre-miR-146 is associated with coronary artery disease risk and its mature miRNA expression. Mutat Res 761: 15-20, 2014.

ZAMPETAKI A, MAYR M: Analytical challenges and technical limitations in assessing circulating MiRNAs. Thromb Haemost 108: 592-598, 2012.

ZAMPETAKI A, DUDEK K, MAYR M: Oxidative stress in atherosclerosis: the role of microRNAs in arterial remodeling. Free Radic Biol Med 64: 69-77, 2013.

ZHANG T, LI L, SHANG Q, LV C, WANG C, SU B: Circulating miR-126 is a potential biomarker to predict the onset of type 2 diabetes mellitus in susceptible individuals. Biochem Biophys Res Commun 463: 60-63, 2015.

ZHANG Y, WANG S, LI Y, ZHANG C, XUE J, WU X, WANG C: Relationship of microRNA 616 gene polymorphism with prognosis of patients with premature coronary artery disease. Int $J$ Clin Pharmacol Ther 54: 899-903, 2016.

ZHU H, FAN GC: Extracellular/circulating microRNAs and their potential role in cardiovascular disease. $A m J$ Cardiovasc Dis 1: 138-149, 2011. 